\title{
Fenomén migrace z pohledu ideje rozvoje společného domova obsažené v sociálním učení církve, zvláště ve vyjádřeních papežư Benedikta XVI. a Františka Jindřich Šrajer
}

\section{Úvod}

Když v novoročním projevu v roce 2001 tehdejší prezident České republiky Václav Havel charakterizoval svět, ve kterém žijeme, a pokusil se přitom vyjádřit domnělé pocity nemnohých, hovořil o nepřehledném, trochu drsném a trochu bláznivém světě, kterému je těžké porozumět a zároveň je možné pochybovat o dobrém smyslu mnoha věcí, které určují jeho pohyb. ${ }^{1} \mathrm{~S}$ odstupem času je možné Havlova slova považovat za stále platná. Zdá se, že se v současnosti svět propadá do stále většího chaosu. V dnešním světě není snadné se orientovat, nalézat jeho pravý smysl ani původ věcí, které určují jeho pohyb. Přesto je možné s jistou určitostí tvrdit, že terorismus, lokální válečné konflikty, ale také chudoba a špatné podmínky k životu v některých částech světa jsou v současnosti především těmi jevy, které podněcují globální chaos a strach. ${ }^{2}$ Nebývalé množství obyvatelstva se dává do pohybu. Jedni utíkají z ohrožených území, aby zachránili holý život. Jiní proto, že hledají prostředky k životu nebo nový domov. ${ }^{3}$ Problémem, především politiků, je, že stěží dokáží - existuje dokonce i podezření, že někdy spíše nechtějí - nalézat skutečné příčiny nastalého chaosu a účinně řešit s tím spojené problémy. Silná migrační vlna se valí do Evropy, zvláště té Západní. Evropa je v důsledku toho konfrontována se svými humanistickými kořeny. Patří k nim respekt $\mathrm{k}$ důstojnosti člověka a jeho právům, solidarita, pomoc potřebným atd. Papež František připomíná, že se za této situace nemůže Evropa zpronevěřit sobě vlastním hodnotám. ${ }^{4}$

Církev, která po celé své dějiny považovala péči o cizince, lidi na cestách a od nedávné minulosti také pomoc imigrantům a přistěhovalcům za důležitou oblast sociálního zájmu, považuje migraci na začátku třetího tisíciletí za význačný sociální jev, který vyvolává závažné společenské, ekonomické, politické, kulturní a náboženské problémy, které staví jednotlivé národy i mezinárodní

1 Srov. (C) Václav HAVEL, Novoroční projev prezidenta ČR, 1. 1. 2001 (on-line), dostupné na: http://archive.vaclavhavel-library.org/ viewHavelWork_event.php, citováno dne 28. 5. 2016.

2 Papež František se nebojí v této souvislosti opakovaně hovořit o třetí světové válce, která se podle něho uskutečňuje po kouskách. Srov (c) Společné prohlášení papeže Františka a ekumenického patriarchy Bartoloměje (on-line), dostupné na: http://www.radiovaticana.cz/ clanek.php4?id=23604, citováno dne 23. 6. 2016.

3 Za mohutnou vlnou uprchlíků valící se do Evropy nejsou jen válečné konflikty, třebaže podstatně ano, ale také zhoršující se životní podmínky v jednotlivých zemích. Podle některých lze právě z důvodu klimatických změn očekávat v budoucnu další mohutnou migrační vlnu, která zaplaví Evropu. Problém migrace tak není jen naléhavým problémem dneška, ale i zítřka.

4 Srov. (C) Společné prohlášení papeže Františka a ekumenického patriarchy Bartoloměje; dále srov. FRANTIŠEK, Sním o Evropě jako o matce, Perspektivy, KT 21/2016, s. 7. 
společenství před dramatické výzvy, které nemají jednoduchých řešení ani zřetelných odpovědí. ${ }^{5}$ Ještě před v současnosti kulminující masivní migrační vlnou, která nemá v Evropě co do intenzity od 2. světové války obdobu, je v textech sociálního učení církve migrace označována za společenský fenomén epochální povahy, který vyžaduje odvážnou a prozíravou politiku mezinárodní spolupráce, jež se musí odvíjet od těsné spolupráce s původními zeměmi migrantů a zeměmi, které je přijímají. ${ }^{6}$ Migrace je za této situace ze strany církve považována za „Znamení času“, které si vyžaduje náležitou pozornost. ${ }^{7}$

Zde předložené pojednání reflektuje fenomén migrace právě z pozic sociálního učení církve. Nemá a nemůže mít přitom z podstaty věci ambici na několika málo stránkách zachytit epochální problém migrace v celé jeho složitosti a diverzitě. Nedává si ani za cíl představit komplexně historický nástin pojetí migrace v sociálním učení církve v dynamice vývoje a proměn jeho argumentačních linií, které jsou odrazem dynamiky vývoje migrace a migračních proudů v daných obdobích a historických okolnostech a také výrazem dějinného vývoje sociálního učení církve jako celku. ${ }^{8}$ Cílem tohoto pojednání je pouze snaha podívat se na aktuální problém migrace na počátku třetího tisíciletí zvláště pohledem dvou posledních papežů, Benedikta XVI. a Františka. Oba akcentují a do jisté míry i prohlubují či inovují - což je také jedna z otázek našeho pojednání - dva důležité principy, kterými sociální učení církve zdůvodňuje svůj postoj k problematice migrace. $\mathrm{V}$ prostoru vymezeném těmito dvěma principy se odehrává diskuse o zodpovědném „Vypořádání se“ s touto problematikou. Jde při ní o harmonizaci požadavků vyplývajících z jedinečnosti lidské důstojnosti a univerzálních lidských práv s právem suverénních států na příslušnou regulaci migrace (např. formou hraničních kontrol). ${ }^{9}$ Prvním ze zmíněných dvou principů je princip kosmopolitní (myšlenka společného domova, jednoho světa). Druhým je princip politický. První ze jmenovaných principů rozpracovává specifickým způsobem papež Benedikt XVI., zvláště s ohledem na nedávnou světovou ekonomickou a finanční krizi, v encyklice Caritas in veritate (2009). Papež František se na tento princip odvolává ve svých aktuálních vyjádřeních nejen ve vztahu k migraci, ale také ve vztahu k aktuálním ekologickým otázkám, které reflektuje ve své první sociální encyklice Laudato si' (2015). Podle našeho přesvědčení vyjádření zmíněných dvou papežů opřená o uvedené principy, zvláště pak ten kosmopolitní, nastolují otázky po jejich opodstatněnosti, resp. po opodstatněnosti požadavků, které se od nich odvíjejí směrem k řešení problému migrace. Jinak řečeno, jde především o relevantnost ze strany obou papežů formulovaných nezbytných předpokladů, které zmíněné řešení podmiňují. Tyto předpoklady se pojí s otázkou po roli či významu křestanské víry, potažmo křestanů a církve v globálním světě, resp. po tom, nakolik je ve světě možná realizace univerzálního bratrství.

\section{Myšlenka společného domova - univerzální bratrství}

Kosmopolitní princip lze bezesporu považovat za základní východisko a důležitý referenční bod sociálně-etické reflexe otázek spojených se soudobou migrační krizí. ${ }^{10}$ Je dobré si uvědomit, že

5 Srov. Poselství papeže Jana Pavla II. koslavě světového dne míru 1. ledna 2001, Praha: ČBK, 2000, čl. 12, 13; srov. také BENEDIKT XVI., Caritas in veritate, Kostelní Vydří: KNA, 2009, čl. 62. Dále v textu pouze CV a číslo př́slušného oddílu.

6 Srov. CV 62.

7 Srov. PAPEŽSKÁ RADA PRO PASTORACI MIGRANTU゚ A LIDÍ NA CESTÁCH, Erga migrantes caritas Christi (3. 5. 2004), Praha: ČBK, 2006, čl. 1-11.

8 Zmíněnou problematiku přehledně pojednává Petr ŠTICA, Migrace v sociálním učení církve, AUC THEOLOGICA 1/2012, s. 113-135.

9 Srov. tamtéž, s. 128

10 Srov. tamtéž, s. 131. 
chápání světa jako jednoho Božího stvoření, jako společenství všech lidí, kteří jsou si principiálně rovni, je v základu biblické a křestanské tradice. ${ }^{11} \mathrm{~V}$ sociálním učení církve je kosmopolitní princip úzce provázán s principem personality. Vychází se z toho, že každý člověk, stvořený k Božímu obrazu (srov. Gn 1,27), bez ohledu na státní př́slušnost, která je v tomto směru podružná, má jedinečnou, neodnímatelnou důstojnost. Každý člověk je nositelem lidských práv, což mimo jiné vylučuje jakoukoli formu rasismu či xenofobie. Významným předělem v dějinách křestanského myšlení je v tomto směru II. vatikánský koncil, který v souladu s obnovenou eklesiologií odráží "nové vědomí křestanů o způsobu, jak být opravdovým společenstvím věŕících a lidem Božím“. ${ }^{12}$ Znamená to mimo jiné obnovený zájem o dosavadní sociální učení církve, ${ }^{13}$ o potřeby současného člověka a světa, se kterými se církev solidarizuje. V tomto směru nejvýznamnější dokument II. vatikánského koncilu, pastorální konstituce Gaudium et spes (1965), reflektuje i globální kontext sociální reality. Navrhovaná řešení sociálních otázek - jako např. sociální a ekonomické nerovnosti mezi jednotlivými národy a kontinenty či pomoc uprchlíkům a imigrantům - promýšlí na bázi požadované solidární mezinárodní spolupráce. ${ }^{14} \mathrm{~V}$ návaznosti na otázku po správné interpretaci hospodářského rozvoje připomíná též myšlenku univerzálního určení statků a posiluje koncepci integrálního lidského rozvoje. ${ }^{15}$

Pastorální konstituci Gaudium et spes lze bezpochyby v tradici sociálního učení církve, jak již bylo naznačeno, považovat $\mathrm{v}$ řadě ohledů za přelomovou. ${ }^{16} \mathrm{Z}$ našeho pohledu je to obzvláště $\mathrm{v}$ ní prezentovaný postoj ke světu a sociální realitě v procesu postupující a prohlubující globalizace, který posiluje vědomí sjednocujícího lidstva. Dá se však říct, že co zmíněná pastorální konstituce jakoby pouze naznačuje, nalézá nový výklad a bohatou syntézu, jakož i odpověd na v ní obsažené výzvy teprve v encyklice papeže Pavla VI. Populorum progressio (1967). Ta na koncilní myšlenky, zvláště pak na Gaudium et spes, bezprostředně navazuje. Uplatňuje jeho sociální učení na specifickou otázku rozvoje a zaostávání národů. ${ }^{17}$ Encyklika reflektuje postkoloniální dobu (rozpad koloniálních mocností) a rodící se zásadní sociální geografický konflikt mezi bohatým Severem a chudým Jihem. Zvláště si všímá toho, že chudé země jsou ze strany těch bohatých zemí vystaveny četným nespravedlnostem, ponižování a diskriminaci, což jim znemožňuje opravdový rozvoj. ${ }^{18}$ Papež Pavel VI. vybízí v této souvislosti k mezinárodní solidaritě bohatých zemí s chudými. ${ }^{19}$ Činí tak s odkazem na potřebu integrálního rozvoje člověka a solidární rozvoj lidstva, což jsou dvě ústřední linie jeho encykliky.

Význam encykliky Populorum progressio spočívá nakonec právě v šírii obzoru, se kterou se zde po-

11 Srov. k tomu Petr ŠTICA, Cizinec v tvých branách: Biblické podněty pro etickou reflexi migrace, Praha: Karolinum, 2011, s. 94-104.

12 KONGREGACE PRO KATOLICKOU VÝCHOVU, Sociální nauka církve. Instrukce pro studium a vyučování, Řím, 1988, Brno, 1991, s. 25.

13 Jan Pavel II. připomíná, že se zde projevila péče církve, která prodchla práci celého koncilu, o shrnutí a další rozvíjení sociálního učení. Srov. JAN PAVEL II., Sollicitudo rei socialis (1987), in: Sociální encykliky (1891-1991), Praha: Zvon, 1996, čl. 6. Dále v textu pouze SRS a číslo příslušného oddílu.

14 Srov. Dokumenty II. vatikánského koncilu, Praha: Zvon, 1995. Pastorální konstituce Gaudium et spes, čl. 84-86. Dále v textu pouze GS a číslo př́slušného oddílu.

15 Srov. GS 69. Člověk je zde prezentován jako „původce, střed a cíl veškerého hospodářsko-společenského života“. (GS 63) Hlavním úkolem výroby má být podle koncilu „služba člověku, celému člověku v jeho hmotných potřebách i v požadavcích jeho intelektuálního, mravního, duchovního a náboženského života, služba každému člověku i každé skupině lidí jakékoli rasy a z kterékoli části světa“. (GS 64)

16 K významu dokumentu Gaudium et spes srov. Jindřich ŠRAJER - Lucie KOLÁŘOVÁ a kol., Gaudium et spes. Padesát let poté, Brno: CDK, 2015.

17 Srov. SRS 6, 7.

18 Srov. PAVEL VI., Populorum progressio (1967), in: Sociální encykliky (1891-1991), Praha: Zvon, 1996, čl. 56-66. Dále v textu pouze PP a číslo př́slušného oddílu.

19 Srov. PP 45-55. 
jednává „sociální otázka“. Teprve v této encyklice dozrává sociální učení církve k tomu, že může již naplno prohlásit na základě objektivního rozboru světové situace, že „sociální otázka nyní nabyla světových rozměrư “ ${ }^{20} \mathrm{a} \mathrm{v}$ návaznosti na to se také snažit nabídnout „směrnice pro konkrétní jednání“ ${ }^{21}$ Rozhodující přínos této encykliky, který chceme na tomto místě rozvinout i vzhledem $\mathrm{k}$ současnému problému migrace a imigrace, spočívá ale především $\mathrm{v}$ tom, že celosvětový význam sociální otázky je zde prezentován jako morální skutečnost, která se dotýká každého člověka. Papež Jan Pavel II. za pomoci slov zmíněné encykliky „dnes nejvíce záleží na tom, aby všichni byli přesvědčení a cítili," ${ }^{\prime 2}$ připomíná, „že se tato (celosvětová) záležitost př́mo týká svědomí, které je zdrojem mravních rozhodnutí' ${ }^{23} \mathrm{Z}$ morálního hodnocení celosvětového významu sociální otázky pak podle papeže Jana Pavla II. vyplývá, že „také osoby zodpovědné za veřejné záležitosti a s nimi i jednotliví občané bohatých zemí, především jsou-li křestané, mají podle př́íslušného stupně své odpovědnosti mravní povinnost brát při svých osobních a veřejných rozhodnutích zřetel na tento univerzální vztah, na tuto vzájemnou závislost mezi svým chováním a bídou a nedostatečným rozvojem tolika miliónů lidí. Řečeno ještě přesněji, encyklika Pavla VI. zdůrazňuje tuto morální povinnost jako ,povinnost solidarity.“ ${ }^{\text {“24 }}$

Je to bezesporu, zdá se, především právě ono výše zmíněné „morální jádro“ výpovědi encykliky Populorum progressio, které má na mysli i papež Benedikt XVI., když označuje tuto encykliku v Caritas in veritate (2009) za „Rerum novarum naší doby“ a snaží se aktualizovat její učení vzhledem $\mathrm{k}$ novým požadavkům doby. ${ }^{25}$

$\mathrm{V}$ encyklice Caritas in veritate s podtitulem O integrálním lidském rozvoji v lásce a v pravdě se papež Benedikt XVI. při nahlížení celosvětové sociální reality jako morální skutečnosti zaměřuje především na roli církve, specifický význam křestanství, resp. realizaci křestanských hodnot ve světě, bez nichž podle něho není integrální lidský rozvoj možný. Vychází přitom z předpokladu lásky jako daru, milosti (charis), ${ }^{26}$ která se má realizovat v pravdě, přičemž onou pravdou je „zároveň pravda víry i rozumu, v rozlišení i v součinnosti obou těchto oblastí poznání “. 27 Dovoluje mu to nejen poukazovat na nebezpečí současné doby, ale i rozkrývat či předestírat její perspektivy. Papežem prezentovaná nebezpečí a možné perspektivy současného člověka, potažmo lidstva, a doby se vzhledem $\mathrm{k}$ námi reflektované problematice migrace pokusíme blíže připomenout.

Benedikt XVI. zdůrazňuje „objektivní“ charakter principu lásky v pravdě, jenž tvoří dialog, komunikaci a společenství. Pravda jako logos totiž „umožňuje lidem vykročit z jejich subjektivních mínění a dojmů, dovoluje jim překračovat kulturní a historická omezení, vzájemně se setkávat a ocenit skutečnou hodnotu a podstatu věcí ${ }^{\prime 28}$ Jak píše papež dále, ,jestliže v současném společenském a kulturním kontextu, $v$ němž je rozšiřrena tendence pravdu relativizovat, žijeme lásku v pravdě, docházíme k poznání, že přijmout hodnoty křestanství je nejen užitečný, ale přímo

26 Srov. CV 5. Byt’ nám v následující prezentaci myšlenek encykliky CV nejde o celkové hodnocení tohoto dokumentu, lze přesto na tomto místě alespoň poukázat na některé kritické komentáře k sociálně etickému paradigmatu zmíněné encykliky. Srov. např. Gerhard KRUIP, Caritas in veritate. Ein kritischer Kommentar aus sozialethischer Perspektive, Theologie und Glaube 100/2010, s. 85-107. 
nezbytný prvek pro vytváření dobré společnosti a pro opravdový a integrální rozvoj člověka“.29 V návaznosti na zde řečené papež zároveň připomíná, že „bez pravdy, bez důvěry a bez lásky $\mathrm{k}$ pravdě neexistuje společenské svědomí ani odpovědnost. Společenské jednání se pak stává hř́č́kou soukromých zájmů a logiky moci, což má rozkladné účinky na společnost, tím spiše na globalizující se společnost v současných obtížných časech. “30

Benedikt XVI. tak vidí prímou úměru mezi nebezpečími dnešní doby ve světě postupující a prohlubující se globalizace a velikostí výzvy pro církev a křestany realizovat princip lásky v pravdě. Nebezpečí současné doby spočívá podle něho v tom, „že faktickému vzájemnému propojení mezi lidmi a národy neodpovídá žádná etická interakce svědomí a rozumu, z níž by měl ve výsledku vzejít skutečný lidský rozvoj. Jedině láskou, kterou osvěcuje světlo rozumu a víry, lze dosáhnout cílů rozvoje, jež mají více lidskou a více zlidštující hodnotu. To, aby lidé mohli sdílet statky a zdroje, z nichž vychází opravdový rozvoj, nelze zajistit jenom technickým pokrokem a jenom vztahy založenými na užitečnosti, nýbrž potenciálem lásky, která přemáhá zlo dobrem (srov. Řím $12,21)$ a která lidi v jejich svědomí a svobodě činí otevřenými pro vzájemnost. ${ }^{\text {“31 }}$ Jinými slovy řečeno, papež Benedikt XVI. chce poukázat na univerzálně spásný rozměr lidské existence, který podněcuje lidskou vzájemnost a solidaritu. Prakticky to znamená, že „lidská obec se nerozvijí pouze díky vztahům, založeným na právech a povinnostech, ale mnohem víc a na prvním místě díky vztahům, charakterizovaným nezištností, milosrdenstvím a společenstvím “ ${ }^{32}$ Usilí o spravedlnost a společné dobro oživované láskou tak „přispívá $\mathrm{k}$ budování oné univerzální obce Boží, $\mathrm{k}$ níž směrují dějiny lidské rodiny. Společné dobro a úsilí o ně v globalizující se společnosti proto nutně nabývá dimenzí celé lidské rodiny, to je společenství národů a států, a to tím, že lidské obci dávají formu jednoty a pokoje, čímž do určité míry předjímají a předobrazují ničím neomezenou obec Boží. “33

Papežem Benediktem XVI. výše položený důraz na „vzájemnou souvislost mezi snahami o sjednocení lidstva a křestanským ideálem jediné rodiny národů, solidární ve společném bratrství, ${ }^{\text {“34 }}$ se opírá o přesvědčení, že „integrální lidský rozvoj je především povolání “, ${ }^{35}$ které vyžaduje na jedné straně pochopení toho, že „bez perspektivy věčného života postrádá lidský pokrok v tomto světě rozlet (...). Lidstvo pak ztrácí odvahu přijímat vyšší dobra a ujímat se velkodušných a nezištných iniciativ, k nimž vybízí univerzální láska. ${ }^{\text {"36 }} \mathrm{Na}$ druhé straně to vyžaduje podle Benedikta XVI. od každého člověka svobodné a solidární přijetí odpovědnosti. Integrální lidský rozvoj tak vyžaduje transcendentní vizi lidské osoby, potřebuje Boha, protože teprve setkání s Bohem umožňuje člověku „nevidět , $\mathrm{v}$ tom druhém jen druhého', ale rozeznávat $\mathrm{v}$ něm božský obraz, a tak druhého opravdu objevit a dozrát k lásce, která se stává starostí o druhého a péćí o něho“““37

Výše uvedené myšlenky mají $\mathrm{k}$ fenoménu migrace jako $\mathrm{v}$ současnosti $\mathrm{k}$ jednomu $\mathrm{z}$ klíčových aspektů integrálního rozvoje ${ }^{38}$ svoji nepochybnou relevantnost. Vyžaduje-li podle Benedikta XVI. integrální lidský rozvoj od každého člověka svobodné a solidární přijetí odpovědnosti, zname-

\footnotetext{
29 Tamtéž.

30 CV 5.

31 CV 9.

32 CV 6.

33 CV 7.

$34 \mathrm{CV} 13$.

35 CV 11. 
ná to zároveň odmítnutí logiky, že rozvoj, jakož i př́pady zaostalosti jsou dílem náhody nebo dějinné nutnosti a neplynou z lidské odpovědnosti. Volají-li podle Pavla VI. a Benedikta XVI. „národy trpící hladem (...) s náŕkem o pomoc k národům, které mají blahobyt, ${ }^{\text {“39 }}$ představuje to také „povolání, výzvu svobodných lidí $\mathrm{k}$ jiným svobodným lidem, $\mathrm{k}$ společnému přijetí odpovědnosti “. ${ }^{40}$ Nakonec tak jen v prostředí odpovědné svobody - předpokládá se u jednotlivce i u národů - se může přiměřeně dařit integrálnímu rozvoji. ${ }^{41}$ Zmínění papežové pak v návaznosti na řečené opakovaně zdůrazňují, že příčiny zaostalosti není třeba spatřovat v materiální rovině, nýbrž v nežádoucích dimenzích lidské osoby. „Ve vůli, která často nedbá na požadavek solidarity (a)

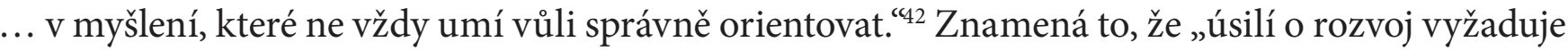
,lidi moudré, přemýšlivé, hledající nový humanismus, který by umožnil modernímu člověku najít

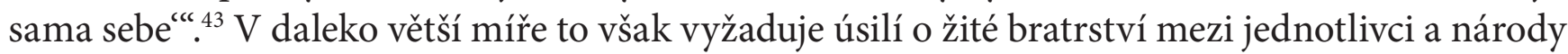
jako projev transcendentního povolání. Právě nedostatek tohoto bratrství se totiž ukazuje být skutečnou příčinou zaostalosti. ${ }^{44}$ Benedikt XVI. v této souvislosti připomíná: „Stále globalizovanějši společnost $\mathrm{z}$ nás dělá sousedy, ale ne bratry. Rozum sám o sobě je schopen pochopit rovnost mezi lidmi a postarat se o klidné občanské soužití - nedokáže ale vytvořit bratrství. Bratrství má svůj původ v transcendentním povolání od Boha Otce, který si nás zamiloval jako první a který nás skrze Syna učí, co je bratrská láska. ${ }^{“ 45}$

Myšlenka univerzálního bratrství - jedním z jeho základních projevů je právě nezištnost ${ }^{46}$-, jehož realizace je podmiňována rozměrem křestanské víry, je bezesporu teologicky obhajitelná. Neznamená to ovšem, domníváme se, že tím chce Benedikt XVI. říci, že lidé, kteří nesdílejí křestanskou víru, nemohou být jeho spolupodílníky či spolutvưrci. Sám Benedikt XVI. totiž zdůrazňuje, že „pravda stejně jako láska ,... se v jistém slova smyslu lidské bytosti ukládá‘. (...) Láska v pravdě je darem, který obdrželi všichni, je opravdu silou, která utváří komunitu a která lidi sjednocuje způsobem, v němž neexistují žádné přehrady či hranice. ${ }^{477}$ Tuto naši domněnku lze podepř́t $\mathrm{i}$ poukazem na nabídku, kterou učinil Benedikt XVI. ještě jako kardinál Ratzinger nevěřícím přátelům, když je vybízel $k$ tomu, aby se přesto, že nedokáží věřit v Boha, snažili svůj život zaměřovat tak, jako kdyby Bůh byl (veluti si Deus daretur), čímž, jak říká, „všechny naše věci nacházejí oporu a měřítko, jehož mají naléhavě zapotřebí “ ${ }^{48}$ Podobně inspirativní je v tomto směru i myšlenka Václava Havla, kterou vyjádřil ve výše zmíněném novoročním projevu. V onom nejenom pro něho nepřehledném a trochu bláznivém světě odkazuje na „nadějeplný bod“, na fenomén svědomí. Připomíná, že každodenní věrnost svědomí svědčí o mravním cítění a schopnosti etického soudu ve společnosti, $v$ níž se tím vytvárí husté předivo pozitivních jevů a vztahů, o kterém je potřeba vědět, vypovídat o něm a přetvářet ho do trvalých a odolných společenských skutečností. Co je však v Havlově pojetí důležité, je skutečnost, že poukazuje na transcendentní rozměr svědomí. Hovoří přitom o „podvědomém, hluboce zakořeněném předpokladu, že se přece jen někde všechno a navždy ví, a že nic tudíž neunikne spravedlivému soudu. Všichni přece víme," jak říká dále, „že nemáme zrazovat př́tele, krást, lhát, pohrdat někým proto, že má jiný tvar očí nebo tělesnou vadu, nerespektovat společné zájmy, byt by náš vliv na jejich ochranu byl sebemenší, a že

39 PP 3; CV 17.

40 CV 17.

41 Srov. tamtéž.

42 CV 19.

43 Tamtéž.

44 Srov. PP 66; CV 19.

45 CV 19.

46 Srov. CV 34.

47 Tamtéž

48 Joseph RATZINGER, Evropa Benedikta z Nursie v krizi kultur, Kostelní Vydří: KNA, 2006, s. 41. 
máme myslet i na to, co se děje daleko od nás nebo co se bude dít dlouho po nás. ${ }^{49}$

Výše uvedené skutečnosti nás vedou k bližšímu pochopení specifického významu či př́nosu křestanství pro realizaci - Benediktem XVI. opakovaně připomínaného - univerzálního bratrství založeného na myšlence lidského rodu jako jediné rodiny, resp. role křestanství v kontextu jiných kultur a náboženství a těch, kteří náboženskou víru nesdílejí. Pomineme-li s tím spojené některé další skutečnosti, ${ }^{50}$ je možné na tomto místě vyzdvihnout především Benediktem XVI. požadovaný dialog mezi vírou a rozumem, který podle něho „může učinit působivějším dílo lásky ve společnosti a zároveň tvoří nejvhodnější rámec pro podněcování bratrské spolupráce mezi věřícími a nevěřícími v jejich společném závazku pracovat pro spravedlnost a pokoj lidské rodiny“ “ ${ }^{51}$ Před věřícími přitom vyvstává „povinnost sjednocovat své úsilí se všemi muži a ženami dobré vůle, patřícími k jiným náboženstvím nebo nevěřícími, aby tento náš svět skutečně odpovídal božskému plánu - žít jako jedna rodina před zraky Stvořitele“ ${ }^{52}$ Nejlepší cestou k naplnění bratrské lásky a spolupráce je přitom podle Benedikta XVI. zásada subsidiarity a solidarity, které se obzvlášt hodí „pro zvládání globalizace i pro její nasměrování k pravému rozvoji člověka“. ${ }^{33}$

Důraz na spolupráci všech bez rozdílu náboženského přesvědčení v kontextu společného domova, který společně sdílíme, nalézáme i u papeže Františka. Tato myšlenka je v základu jeho sociální encykliky Laudato si' (2015), s př́iznačným podtitulem Encyklika o péči o společný domov. Papež se v ní zabývá všemi vztahy, do kterých je člověk zasazen, primárně pak jeho vztahem k př́rodě. Byt’ konstatuje, že „náš společný domov velice chátrá “, ${ }^{44}$ protože „lidstvo zklamalo Boží očekávání“, 55 vyjadřuje současně naději, „že vždy existuje východisko, že stále můžeme změnit směr a vždy můžeme něco udělat pro řešení problémư“. ${ }^{56}$ Papež František vidí východisko potřebné změny právě ve „vědomí společného původu, vzájemné sounáležitosti a společně sdílené budoucnosti“ ${ }^{57}$ které „by umožnilo zrod nových přesvědčení, nových postojů a životních stylü“ ${ }^{58}$ Mluví o potřebě změny samotného lidstva, když připomíná, že „mnohé nynější sociální problémy je třeba vnímat v souvislosti s egoistickým hledáním bezprostředního uspokojení, s krizí rodinných a sociálních vztahů a s neschopností uznávat druhého “. ${ }^{59}$ Papež František v této souvislosti vybízí k tomu, abychom si uvědomili, „že se vzájemně potřebujeme, že neseme zodpovědnost jedni za druhé a za svět". ${ }^{60}$ Poukazuje na základní postoj sebetranscendence, který rozbíjí izolované a sebevztažné vědomí a umožňuje péči o druhé. ${ }^{61}$

Papež František tak sobě vlastním, osobitým zpơsobem navazuje na myšlenky obsažené v křestanské tradici. Ve vztahu k migraci je to především jeho osobitý důraz na milosrdnou lásku, na vnímavost k potřebným. Připomíná v této souvislosti, že „úmyslem Boží lásky (...) je dostat se ke všem a ke každému, aby ti, kdo Otcovo objetí přijímají, se sami proměňovali v otevřenou a

49 () Václav HAVEL, Novoroční projev prezidenta ČR. Srov. k tomu také FRANTIŠEK, Laudato si'. Bud' pochválen. Encyklika o péči o společný domov, Praha: Paulínky, 2015, čl. 212, 232. Dále v textu pouze LS a číslo př́íslušného oddílu.

50 Srov. k tomu CV 54-57.

51 CV 57.

52 Tamtéž.

53 Tamtéž.

54 LS 61.

55 Tamtéž.

56 Tamtéž.

57 LS 202.

58 Tamtéž.

59 LS 162.

60 LS 229.

61 Srov. LS 208. 
objímající náruč, aby každý věděl, že je milován jako syn, a cítí se být ,doma` v jedné lidské rodině““ ${ }^{62}$ Připomíná, že „migranti a uprchlíci jsou pro nás výzvou“, ${ }^{63}$ jsou našimi bratry a sestrami, přičemž prožitek Božího milosrdenství nás má stimulovat $\mathrm{k}$ solidaritě s bližním jako odpovědi na bezplatnou Boží lásku. Každý z nás je, jak připomíná dále, zodpovědný za svého bližního; jsme strážci svých bratří, at žijí kdekoliv. Mluví v této souvislosti o „kultuře setkání, která překonává předsudky a obavy a pečuje o dobré osobní vztahy. Je připravena dávat, ale i přijímat od druhých. ${ }^{64}$ Ta jediná je podle něho „schopná vytvářet spravedlivější a více bratrský, lepší svět““ ${ }^{65}$

\section{Migrace jako politický problém - principy řešení}

Výše prezentovaný kosmopolitní princip a $\mathrm{v}$ jeho rámci rozvíjené myšlenky jsou, jak již bylo řečeno, pro sociální učení církve základním výchozím bodem či vymezením pro oblast politiky, která je oprávněná, resp. povinná, nalézat adekvátní řešení sociálních problémů, $v$ našem př́ípadě problému migrace. Toto právo a povinnost jí jsou ze strany církve opakovaně připomínány. Na tomto místě se pokusíme formulovat některé principy či požadavky, vyjádřené sociálním učením církve, které by měly být pro podobu této politiky určující.

Předně se sociální učení církve, v návaznosti na problém migrace, dovolává slovy Benedikta XVI. odvážné a prozíravé politiky mezinárodní spolupráce, která se odvíjí od těsné spolupráce $s$ původními zeměmi migrantů a zeměmi, které je přijímají. ${ }^{66}$ Jinak řečeno, úkolem zodpovědných politiků a relevantních institucí je chránit dobro všech lidí, migrantů i stávajícího obyvatelstva zemí, do kterých uprchlíci směřují. Znamená to také vnímat a řešit příčiny a následky migrace a právo na její regulaci. V tomto směru papež František opakovaně kritizuje politické a vládní představitele za pomalost, s jakou se snaží současnou migrační krizi řešit. Má za to, že adekvátními kroky by ji bylo možné předcházet a zmírnit ji, ${ }^{67}$ stejně jako připouští, že není možné otevírat brány uprchlíkům iracionálně. ${ }^{68}$ Přijímání uprchlíků se musí podle něho realizovat vysoce zodpovědně. Hovoří o budování mostů, které se stavějí rozumně, vedením dialogu a integrací. Tyto mosty buduje politika „pohostinnosti a integrace, růstu, práce, ekonomické reformy“ ${ }^{69}$

Specifikovat úkol politiky, jakož i církve vůči fenoménu migrace, se daří papeži Františkovi i pomocí poukazu na její ambivalentnost. Podle papeže migrace „na jedné straně často odhaluje nedostatky a nedokonalosti států a mezinárodního společenství, na druhé straně taktéž ukazuje touhu lidstva po životě jednoty, jež respektuje rozdílnosti, touhu po přijetí a pohostinnosti, které by umožnily spravedlivé rozdělování pozemských statků, ochranu a prosazování důstojnosti a ústředního postavení každé lidské bytosti “ ${ }^{70}$ Církev, resp. křestané, by pak měli být podle papeže

62 ㄷ FRANTIŠEK, Poselství Svatého otce ke Světovému dni migrantů 21. 1. 2016 (on-line), dostupné na: http://www.sdbplzen.cz/farnost/ poselstvi-svateho-otce-ke-svetovemu-dni-migrantu/, citováno dne 22.6. 2016.

63 Tamtéž.

64 Srov. tamtéž.

65 ๑ FRANTIŠEK, Poselství Svatého otce ke Světovému dni migrantů 19. 1. 2014. „Migranti a uprchlíci: na cestě k lepšímu světu“ (on-line), dostupné na: http://www.cirkev.cz/Media/CirkevOld/019186.pdf, citováno dne 24. 6. 2016.

66 Srov. CV 62.

67 Srov. ( Společné prohlášení papeže Františka a ekumenického patriarchy Bartoloměje.

68 Srov. () Papež František pro deník La Croix: Evropa nemůže otevírat brány iracionálně (on-line), dostupné na: http://www.radiovaticana.cz/clanek_print.php4?id=23790, citováno dne 23. 6. 2016.

69 (c) RADIO VATICANA, O migraci a exhortaci o rodině (on-line), dostupné na: http://www.radiovaticana.cz/clanek_print. php4?id=23617, citováno dne 23. 6. 2016.

70 ๑ FRANTIŠEK, Poselství Svatého otce ke Světovému dni migranti̊ 19. 1. 2014 
Františka prvními - měli by v tom pomáhat i ostatním -, kdo vidí „v migrantovi a v uprchlíkovi nejen problém, který je třeba řešit, ale i bratra a sestru, jež je třeba přijmout, respektovat a milovat, a př́ležitost, kterou (...) nabízí Boží Prožretelnost; abychom vytvářeli spravedlivější společnost, dokonalejší demokracii, solidárnější stát, bratrštější svět a otevřenější křestanskou společnost podle evangelia“. ${ }^{71}$ Podle papeže Františka může migrace dokonce dát „zrod př́ležitostem pro novou evangelizaci a může otvírat prostory pro růst nového lidstva, které se ohlašuje ve velikonočním tajemství - lidstva, pro něž každá cizí země je vlastí a každá vlast je cizinou“.72

Papež František nakonec připomíná, že řešení současného problému migrace vyžaduje hluboké vědomí solidarity a soucitu $\mathrm{s}$ trpícími, $\mathrm{s}$ lidmi v nouzi, protože prŕćčinami migrace jsou sociálně-ekonomická nerovnováha a neřízená globalizace, která z lidí vytváří spíše oběti než jejich aktéry. Na základě tohoto zjištění se pak dovolává „společn(é) práce pro lepší svět, který vyžaduje vzájemnou pomoc zemí, disponibilitu a důvěru bez toho, že by se vytvářely nepřekonatelné překážky“" ${ }^{73}$ Tomu by mělo na jednu stranu předcházet „úsilí, které by měla každá země vynakládat na vytváření lepších domácích ekonomických a sociálních podmínek, tak, aby emigrace nebyla jedinou volbou pro toho, kdo hledá mír, spravedlnost, bezpečnost a úplnou úctu k lidské důstojnosti “ ${ }^{74}$ Vytváření pracovních příležitostí v místních ekonomikách by mělo rovněž zabránit rozdělení rodin a zaručit jednotlivcům i skupinám stabilní a klidné podmínky ${ }^{75} \mathrm{Na}$ druhou stranu je zde podle papeže Františka potřeba „překonávání předsudků a zaujatosti ve vztahu k migraci. Nezř́dka totiž prríchod migrantů, uprchlíků, žadatelů o azyl a běženců vyvolává u místního obyvatelstva podezření a nepřátelství. Rodí se strach $\mathrm{z}$ toho, že bude docházet k narušení sociální jistoty, že se riskuje ztráta vlastní identity a kultury, že vzroste konkurence na trhu práce anebo že dokonce budou importovány nové faktory kriminality. ${ }^{176} \mathrm{~V}$ této souvislosti upozorňuje papež František na významnou roli a odpovědnost masmédií. Jejich úkol vidí v tom, „aby odhalovaly stereotypy a nabízely korektní informace, aby tam, kde bude třeba, poukazovaly na chyby některých, ale také přibližovaly čestnost, poctivost a velkorysost většiny “. ${ }^{77}$

\section{Závěr}

Cílem tohoto pojednání nebylo reflektovat vyčerpávajícím způsobem složitou problematiku migrace. Cílem nebylo ani nabídnout komplexní pohled na měnící se postoj církve v rámci jejího sociálního učení $\mathrm{k}$ této problematice. Snahou bylo především předestřít myšlenkovou hloubku či šíŕku dvou principů, na které se sociální učení církve odvolává při zdůvodnění svých postojů vůči migraci. Zaměřili jsme se přitom zvláště na reflexi pozic papežů Benedikta XVI. a Františka, kteří v současnosti reprezentují vrcholné rozvinutí těchto dvou principů vůči současným sociálním otázkám, ke kterým neodmyslitelně patři právě i zde zmiňovaný naléhavý problém masové migrace. Naše pojednání ukázalo, že zmínění papežové navazují na dosavadní tradici sociálního učení církve. Aktualizují, což je patrné zvláště u Benedikta XVI., myšlenky Pavla VI. obsažené $\mathrm{v}$ encyklice Populorum progressio vzhledem k problémům současné doby. Každý z nich to dělá, jak se ukázalo, sobě vlastním, osobitým způsobem. Zatímco Benedikt XVI. akcentuje především

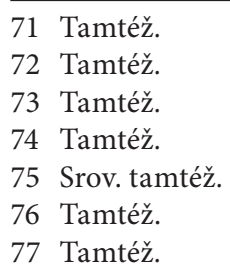


nezastupitelnost křest̉anství, resp. princip lásky v pravdě při utváření humánní podoby světa a jeho rozvoje, papež František akcentuje v tomto ohledu především rozměr milosrdné Boží lásky spolu s důrazem na obzvláštní citlivost k potřebám lidí v jakékoli nouzi. Tato citlivost by měla být zvláště patrná v životě jednotlivého křestana i církve.

Význam tzv. kosmopolitního principu, který jsme zde reflektovali, zvýrazňuje především skutečnost, která byla ze strany sociálního učení církve explicitně vyslovena ve zmiňované encyklice Pavla VI. Populorum progressio. Hovoří se v ní prvně o tom, že sociální otázky dneška mají světový rozměr. Hlavní výpovědí této encykliky přitom je, že tato realita je označena za morální skutečnost, která se dotýká svědomí každého člověka a jeho odpovědnosti. Vyplývá z toho povinnost solidarity, která v tomto smyslu znamená, že všichni cítí odpovědnost za všechny. ${ }^{78}$ Právě tento důraz silně rezonuje ve výpovědích papežů Benedikta XVI. a Františka. Cenné na jejich výpovědích přitom je, konkrétně též ve vztahu k problému migrace, že správně diferencují naléhavost jednotlivých výzev a jejich vzájemnou provázanost. Na jedné straně hovoří o nutnosti aktivního př́stupu politiků k nastoleným problémům, které je třeba řešit adekvátně, což v př́ípadě, jakým je právě fenomén migrace, znamená především odvážně a také rychle. Na druhé straně zdưrazňují nezbytnost zahájení procesů změn vědomí, životních postojů a životních stylů, které se týkají všech.

Zohlednění myšlenky jednoty lidského rodu a požadavku univerzálního bratrství je základní či spíše cílovou představou, od které se odvíjí - v podání papeže Benedikta XVI. a Františka - důležité výzvy k realizaci lepšího světa. $\mathrm{V}$ tomto ohledu nepředstavuje fenomén migrace jen problém, nýbrž především výzvu a příležitost, jak konkrétně onu jednotu lidského rodu a univerzální bratrství osvědčit. Je to především výzva pro církev a nás křest̉any, ale i pro všechny lidi dobré vůle, sjednocovat společně úsilí, „aby tento náš svět skutečně odpovídal božskému plánu“.79 Platí zde, že nikdo nemůže být viděn jako cizinec, který si nezasluhuje přijetí a podporu. Kultura přijetí a solidarity je tou, která „upomíná na nutnost vymýtit nerovnost, nespravedlnost a zvůli“ ${ }^{80}$ Dosvědčuje, že „nikdo není zbytečný, přebytečný nebo odepsatelný““ ${ }^{81}$ Znamená též pro hostitelskou komunitu obohacení své totožnosti a ochotu stále rozvíjet inkluzi, kreativitu a úctu k důstojnosti druhého člověka. ${ }^{82}$

\section{Fenomén migrace z pohledu ideje rozvoje společného domova obsaže- né v sociálním učení církve, zvláště ve vyjádřeních papežů Benedikta XVI. a Františka}

\footnotetext{
Abstrakt:

Článek reflektuje fenomén migrace z pozic sociálního učení církve. Jeho cílem je podívat se na aktuální problém migrace na počátku třetího tisíciletí zvláště pohledem dvou posledních papežů, Benedikta XVI. a Františka, a to na základě reflexe dvou principů, kterými sociální učení církve zdůvodňuje svůj postoj k problematice migrace. Prvním ze zmíněných dvou principů je

78 Srov. CV 38.

79 CV 57.

80 () RADIO VATICANA, Papež účastníkưm Světového kongresu pastorace migrantů: Nikdo není cizinec (on-line), dostupné na: http:// www.radiovaticana.cz/clanek_print.php4?id=21119, citováno dne 25. 6. 2016.

81 Tamtéž.

82 Srov. tamtéž.
} 
princip kosmopolitní (myšlenka společného domova, jednoho světa), druhým je princip politický. Zohlednění myšlenky jednoty lidského rodu a požadavku univerzálního bratrství je prítom v podání zmíněných papežů základní či spiše cílovou představou, od které odvijí důležité výzvy $k$ realizaci lepšího světa. $V$ tomto ohledu pro ně fenomén migrace nepředstavuje jen problém, ale především výzvu a př́ležitost, jak konkrétně onu jednotu lidského rodu a univerzální bratrství osvědčit.

Klíčová slova: migrace, sociální učení církve, společný domov, solidarita, integrální lidský rozvoj, kosmopolitní princip

\section{Kontakt na autora}

doc. Jindřich Šrajer, Dr. theol.

Jihočeská univerzita v Českých Budějovicích

Teologická fakulta, Katedra etiky, psychologie a charitativní práce Kněžská 8, 37001 České Budějovice

srajer@tf.jcu.cz 